\title{
Water resources in Chile: The critical relation between glaciers and mining for sustainable water management
}

\author{
Antonio Bellisario¹ abellisa@msudenver.edu; Francisco Ferrando² fferrand@uchilefau. \\ cl, Jason Janke3 jjanke1@msudenver.edu y
}

\begin{abstract}
Rock glaciers and debris covered glaciers are often understudied in comparison to their uncovered glacial counterparts (in which stunning surface ice is clearly visible). However, rock glaciers and debris covered glaciers are more abundant, often cover a larger area, and will continue to supply a water resource once other glaciers have melted. The surface rock and weathered material cover on rock glaciers and debris covered glaciers acts as an insulator to protect internal ice. As a result, they maintain a reservoir of ice that will be released as water as the climate warms. In the Central Andes $\left(31^{\circ}-35^{\circ} \mathrm{S}\right)$, these catchments provide a valuable water source for nearby urban areas such as Santiago, Chile, which supports more than 6 million people. They also provide irrigation water for agriculture, supporting the burgeoning wine industry in Chile. However, rock glacier and debris covered glaciers are often misinterpreted as other landforms, and their water source is unrecognized by many. The objective of this research is to provide a methodology to inventory the extent of debris covered and rock glaciers in a catchment to estimate the amount of water contained within these landforms using GIS and remotely sensed data. This methodology could be used to better assess and sustainably manage the water resources in the Dry Andes in general and in the Aconcagua Basin in particular.
\end{abstract}

Keywords: Glaciers, debris covered glaciers, rock glaciers, mining expansion, sustainable water management.

\section{Recursos hídricos en Chile: La relación crítica entre los glaciares y la minería para el manejo sustentable del agua}

\begin{abstract}
RESUMEN
Los glaciares de roca y los glaciares con cubierta detrítica son a menudo poco estudiados en comparación con sus homólogos los glaciares descubiertos o blancos (en que la impresionante superficie de hielo es claramente visible). Sin embargo, los glaciares de roca y los glaciares con cubierta detrítica son más abundantes, a menudo cubren un área más extensa, y continuarán suministrando una fuente de agua una vez que los glaciares blancos se hayan derretido. La superficie de roca y de material degradado que cubre los glaciares de roca y con cubierta detrítica actúa como un aislante térmico que protege el hielo interno. Como resultado de ello, éstos mantienen una reserva de hielo que se fusiona lentamente mientras el clima se calienta. En los Andes Centrales $\left(31^{\circ}-35^{\circ} \mathrm{S}\right)$, estas cuencas son una valiosa fuente de agua para las cercanas zonas urbanas, como Santiago de Chile, que sostiene a más de 6 millones de personas. También proporcionan agua de riego para la agricultura y apoyan a la próspera industria del vino en Chile. Sin embargo, los glaciares de roca y con cubierta detrítica son a menudo mal interpretados como otras geoformas, y su fuente de agua no es reconocida por muchos. El objetivo de este trabajo es proporcionar una metodología para inventariar la extensión de los glaciares de roca y con cubierta detrítica para estimar la cantidad de agua contenida dentro de éstos mediante el uso de los SIG y teledetección de imágenes satelitales. Esta metodología puede ser utilizada para mejor evaluar y gestionar de manera sustentable los recursos hídricos en la zona de los Andes semiáridos en general, y en la cuenca del Aconcagua en particular.
\end{abstract}

Palabras clave: Glaciares, glaciares de roca y con cubierta detrítica, expansión minera, manejo sustentable del agua.

Recibido el 30 de octubre de 2013, aceptado el 23 diciembre de 2013.

1 Earth and Atmospheric Sciences, Metropolitan State University of Denver. P.O. Box 173362. Denver, CO 80217-3362.

2 Departamento de Geografía, University of Chile, Portugal 084, Santiago, Chile.

3 Earth and Atmospheric Sciences, Metropolitan State University of Denver..O. Box 173362. Denver, CO 80217-3362. 


\section{INTRODUCTION}

This research is part of a more encompassing research that explores the vulnerability and impacts to water resource scarcity associated with higher hydro demand for economic development and global climatic change. It offers some preliminary results on the challenging relationship between mining and glaciers for sustainable water management in Chile. It discusses the tension between the environmental impacts of accelerated water use in the particularly vulnerable area of glaciers and mining expansion in the upper river basins of the Central Andes Mountains. It offers two case studies that analyze the challenges mining expansion is having on Andean glaciers as sources of water.

The first case study analyses the importance of debris covered and rock glaciers in the Estero de Navarro, a sub-catchment of the Juncal river in the Aconcagua River Basin $\left(32^{\circ} \mathrm{S}\right)$. Debris covered and rock glaciers in Chile have been scarcely inventoried and there is little knowledge as to their contribution to runoff. What is known is that they are more abundant in the Central Andes than uncovered glaciers. There are many documented instances where mining companies have destroyed debris covered glaciers and rock glaciers in the pass. The country maintains an inventory of glaciers but it does not have an accurate account of debris covered and rock glaciers. This section argues that it is important to identify areas that have a high occurrence of debris covered and rock glaciers so that ice preserved within these glaciers are not impacted by future mining projects. For this purpose a more accurate methodology for their identification and calculation of their stored water content is offered. This knowledge might strengthen the argument of those advocating to include debris covered and rock glaciers in the development of a sustainable water management approach in Chile.

The second case study offers an evaluation of CODELCO's (the government-owned
Copper Mining Corporation) current proposal to expand the mining operation in the upper catchment of the Blanco River, also located in the Aconcagua River Basin. Mining in the Andes has increased over the last 30 years. Chile is the world's larger copper producing country and one of the largest gold producers. Because of openpit mining in the upper Andes mountains, rock glaciers are being removed for access to copper and gold resources. In fact, rock glacier area in the upper Blanco catchment has been reduced by $1.4 \mathrm{~km}^{2}$ (BRENNING 2008). This section argues that CODELCO's proposal for the expansion of its open-pit copper mine Andina will not only impact directly a series of rock glaciers that will be removed but it will have a series of negative environmental impacts over a large area.

\section{METHODS AND DATA}

\section{Study Area}

The Aconcagua River Basin is located in the Central Andes north of Santiago, within the most populated area of Chile. This river basin provides critical water resources to important economic activities. The Aconcagua Basin comprises 5 catchments (Río Rocín, Rio Colorado, Río Riecillos, Río Juncal, and Río Blanco). The study area is the Estero de Navarro (also known as the Cajón de Navarro). The Estero de Navarro is a sub-catchment of the Río Juncal located in the upper section of the Andes (32 $\left.87^{\prime} \mathrm{S}-32^{\circ} 97^{\prime} \mathrm{S}\right)$. This high altitude environment has been sculpted by glaciers and modified by periglacial processes (Fig. 1). The Estero de Navarro is covered by glaciers, firn, rock glaciers, debris covered glaciers, and other landforms. The landscape is sparsely vegetated and has been mined for gypsum in the past. The watershed is now part of a privately owned and protected reserve. The alpine terrain is rugged, which makes field reconnaissance difficult and time consuming. The Andes Mountains in the Estero de Navarro reach elevations of 5173 m.a.s.l down to 2429 m.a.s.l. 


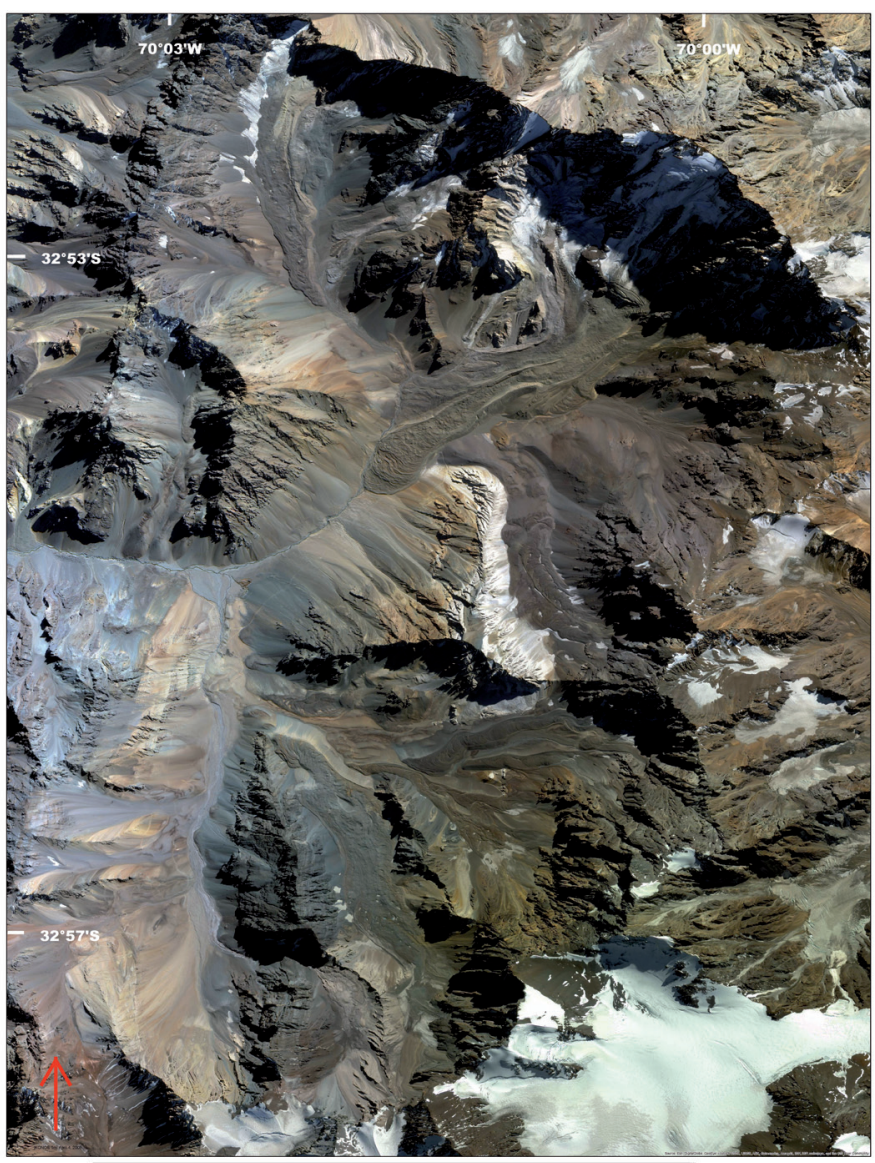

Fig. 1. Location of the study area in the Andes of Chile, IKONOS 1m imagery.

\section{Images and tools}

The background information for this paper is based on an analysis of published and unpublished relevant works. The analysis of the direct and indirect environmental impacts of CODELCO's mining expansion project is based on the project's environmental impact assessment, which is posted online at: http://www.sea.gob.cl.

The remotely sensed data used in the analysis of the Estero de Navarro was: (1) IKONOS 1 $\mathrm{m}$ high resolution imagery; (2) RapidEye $5 \mathrm{~m}$ resolution imagery; and (3) RADARSAT-2 high resolution Synthetic Aperture Radar (SAR) data. The high-resolution $1 \mathrm{~m}$ IKONOS and RapidEye $5 \mathrm{~m}$ imagery are more accurate for mapping geologic landforms, including rock glaciers and debris covered glaciers, than traditional imagery such as Landsat- $830 \mathrm{~m}$ or ASTER $15 \mathrm{~m}$.

ESRI and PCI Geomatics software was used to identify and determine characteristics of landforms in the Estero de Navarro subcatchment. ArcMap was ideal because of its simplified structure to enter and analyze spatial data. Geologic landforms were digitized in ArcMap and tables were easily manipulated for calculations of water content. Deriving statistics, such as zonal statistics, which uses zones of polygons to calculate mean, minimum, maximum, etc., was streamlined with ArcToolbox. ArcScene was used to create flybys of the study area. Geomatica 2013 was used to import and process the Synthetic Aperture Radar (SAR) images. The built in functions and algorithms available in OrthoEngine 
allows a user to create a DEM from stereoscopic SAR pairs with only a few simple inputs. Focus software was used to view and explore the DEM results.

\section{RESULTS}

\section{Mountain and Rock Glaciers}

High mountain systems, the belt above timberline that has been sculpted by glaciers and modified by periglacial processes, remain a focus of much geographic research; however, they are still not readily understood (BARSCH \& CAINE 1984; BARSCH 1996). Changes in Mean Annual Air Temperature (MAAT), net radiation patterns, snow cover distribution, and other variables will alter the processes modifying mountain systems (BENISTON 2000). Anthropogenic climate change and human activities, threaten the nature and stability of high mountain systems (KONRAD \& CLARK 1998). Development in the form of mining projects, hiking paths, camping sites, transportation corridors, pipelines, ski lifts, communication towers, and utility towers continues to occur in alpine regions (GIARDINO \& VICK 1987). As a result, mountains and humans have become delicately interconnected. Rock glaciers are an important component of high mountain systems, often serving as a visible indicator of mountain permafrost (FERRANDO 2003, HAEBERLI 2000). Rock glaciers are found at a variety of locations worldwide. Rock glaciers are often understudied in comparison to their glacial counterparts. According to data obtained from the National Snow and Ice Data Center world database, the locations of all rock glaciers in the world are missing where rock glaciers are known to exist. Scientists continue to debate whether rock glaciers contain ice and if they should be considered glaciers. The Chilean government maintains an online ArcGIS inventory of ice fields, glaciers, and rock glaciers. However, the database is incomplete as obvious rock glacier features are often omitted or missing. Rock glaciers are more abundant, however, in continental climates, often cover a larger area, and will continue to affect the alpine environment once other temperate glaciers have retreated or cease to exist.

Humans have used rock glaciers as a source for construction material, a backdrop for residential areas, dam abutments, drill sites, shaft and tunnel portals, and a water source for urban areas (BURGER et al. 1999). The majority of rock glaciers demonstrate lobate or tongue-shaped forms resulting from a combination of glacial, non-glacial, and periglacial processes. A rock glacier's structure can be generalized as a three-tiered system with a top layer of rock fragments covering a second icecemented or ice-cored interior that overlies rock deposited and overridden by the top layers (HUMLUM 2000). Rock glaciers are most often considered part of a landscape continuum, a cycle describing the transition among glaciers, rock glaciers, and slope deposits (GIARDINO \& VITEK 1988).

Unlike glaciers that are sensitive to extreme fluctuations on a shorter time scale, a strong climatic signal must exist to produce change in a rock glacier system. The debris cover of rock glaciers acts as an insulator to protect internal ice. This debris filters short-term climate anomalies; therefore, rock glaciers are not as sensitive to yearly fluctuations in temperature or snowfall compared to temperate glaciers. As a result, they maintain a reservoir of ice that is likely to be released as water in a warmer, more variable future climate. These catchments might be a valuable water source for nearby urban areas such as Santiago, Chile.

\section{Geospatial Techniques to Detect Debris Covered Glaciers and Rock Glaciers}

Integration of DEM and remote sensing data in a GIS has been used to map rock 
glaciers at a regional scale (JANKE 2001; BRENNING 2009). In the Adam-Presanella Massif of the Italian Alps, BARONI et al. (2004) used GIS and remote sensing to find that active rock glaciers lie below the $-1^{\circ} \mathrm{C}$ MAAT isotherm and are not in equilibrium with the current climate. In the Front Range of Colorado, JANKE (2007) used DEM variables in conjunction with zonal statistics to determine that tongue-shaped rock glaciers occur at higher elevations, northern aspects, and have gentler slopes compared to lobate forms.

Remote sensing has improved our understanding of rock glacier distribution as well as the topoclimates that facilitate rock glacier formation (VITEK \& GIARDINO 1987). HUMLUM (1998) and JANKE (2007) found that rock glaciers and glaciers locations are driven by topoclimates that favor high talus production rates, not regional climates. Topoclimates have also been shown to be important for rock glacier formation; even where rates of insolation are high, such as in the Chilean Andes (BRENNING \& TROMBOTTO 2006). In the Andes, local and catchment slope and potential incoming solar radiation characterize the locations of rock glaciers (BRENNING \& AZOCAR 2010). High elevations, southern or eastern facing aspects, areas with low solar radiation, and slopes less than $20^{\circ}$ favor rock glacier occurrence in the Andes of Argentina (ANGILLIERI 2010).

As new data sources, such as RADARSAT-2, IKONOS and RapidEye imagery, become more readily available, innovative GIS techniques and remote sensing processes need to be explored for efficient detection and mapping. Image fusion techniques utilizing SAR and multispectral data sources can significantly improve the interpretation and classification of land cover based maps (PAUL et al. 2002; HABOUDANE et al. 2002; KÄÄB 2005; AMARSAIKHAN et al. 2011).
Identification of Rock Glaciers and Debris Covered Glaciers to Evaluate Water Supply in the Estero de Navarro Sub-catchment using RADARSAT-2, RapidEye and IKONOS Imagery

Rock glaciers in Chile have been scarcely inventoried and there is little knowledge as to what is their contribution to runoff. What is known is that rock glaciers are more abundant in the Central Andes than uncovered glaciers. The runoff regime of the basins in Northern and Central Chile depends on seasonal snow cover and glacier melt for their water supply. During the summer, when water demand is highest due to high heat stress, ice and snow melt waters in the upper catchments provide most of the streamflow for the river basins (PELLICCIOTTI et al. 2007). And, since debris covered and rock glaciers are very abundant, we hypothesized that they are one of the main contributors to runoff during the summer months.

This preliminary study offers a methodology to elaborate a detailed inventory of glaciers using RADARSAT-2, RapidEye $5 \mathrm{~m}$, IKONOS $1 \mathrm{~m}$, and GIS mapping tools. The high resolution proved to be highly accurately to distinguish different types of glaciers in the Estero de Navarro subcatchment. A classification of three glaciers types that includes, (1) uncovered glaciers, (2) debris covered glaciers, and (3) rock glaciers was used for mapping and for calculating the specific stored water content (in the form of ice) for each type of glacier. This research team is currently conducting a glacier inventory with the same tools employed in the Estero de Navarro for the whole Aconcagua Basin, that which is to be published in the near future. Here we offer a preliminary account of the total number of debris covered and rock glaciers that have been identified to date. 
As for next steps, this research team aims to develop a six-stage typology/ classification of debris covered and rock glaciers of glacial origin based on both morphology and the different amount of ice contained in the core of these glaciers. This classification will be based on empirical evidence derived from observations from our research site in the Estero del Navarro sub-catchment and from in-situ borehole measurement performed by mining companies for mining exploration on rock glaciers. This classification/typology will be used to better estimate the specific stored water content of the different types of glaciers. A model of glacier contribution to runoff will be developed with in-situ measurement of discharge data from the different types of glaciers. This information would be key for those arguing in Chile that rock glaciers should be protected (especially from mining companies) as important sources of water. Chilean water law has no protections toward glaciers in general. Presently, the country is experiencing water scarcity due to the combined effects of climate change and accelerated economic growth.

The high resolution imagery was extremely accurate and ideal for mapping geologic landforms, including rock glaciers and debris covered glaciers. Visible to nearinfrared band combinations allowed better discrimination of feature borders. Given the inaccessibility and ruggedness of the alpine study area in the Estero de Navarro, the high-resolution imagery provided a fast, yet accurate method to identify landforms at a regional scale (Fig. 2). Table 1 summarizes the different landform features identified with this imagery in the Estero de Navarro study area. A field campaign to map all these features would have taken many weeks.

TABLE 1. DESCRIPTION OF LANDFORM FEATURES IDENTIFIED ON THE 1 M IKONOS IMAGERY

\begin{tabular}{|c|c|}
\hline Feature & Description \\
\hline Colluvium & Material deposited by mass wasting (avalanches, landslide, rock fall, etc.). \\
\hline $\begin{array}{c}\text { Debris Covered } \\
\text { Glacier }\end{array}$ & $\begin{array}{r}\text { A receding glacier in which the surface is covered with debris; the thickness is less than } \\
1 \mathrm{~m} \text {; ice content is greater than a rock glacier. }\end{array}$ \\
\hline Debris Flow & $\begin{array}{c}\text { A formerly watery mix of fast moving soil and rock; the movement has since ceased and } \\
\text { a cement-like mixture of material remains. }\end{array}$ \\
\hline Firn & $\begin{array}{c}\text { A body of old snow and ice that does not flow like a glacier, but does not completely } \\
\text { melt during the summer. }\end{array}$ \\
\hline Floodplain & The area found next to a perennial stream that experiences annual flooding. \\
\hline $\begin{array}{c}\text { Glacial Deposition } \\
\text { Glacier }\end{array}$ & Material deposited by glaciers (lateral moraines, recessional moraines, etc.). \\
\hline Outwash & Material deposited by running water, typically from a melting glacier. \\
\hline Rock Glacier & A periglacial feature that has approximately equal mixtures (50-50) of debris and ice. \\
\hline Rugged Terrain & High, relief, and rugged terrain. \\
\hline
\end{tabular}




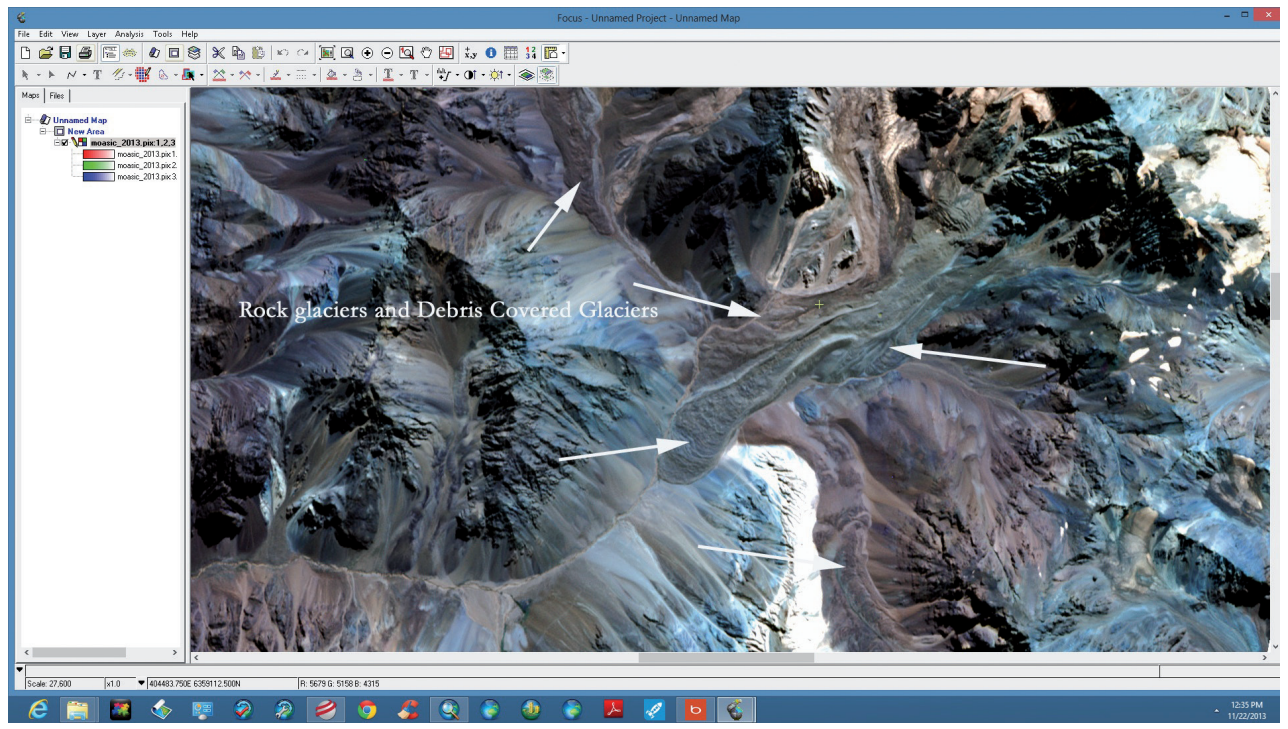

Fig. 2. Examples of rock glaciers and debris covered glaciers that are visible on the RapidEye imagery.

\section{Workflow of the methodology}

Rock glacier and associated geologic landforms were digitized as polygons in
ArcGIS. Topology tools in ArcToolbox and other editing tools were used to clean the dataset, remove overlapping polygons, and eliminate slivers in the dataset (Fig. 3).

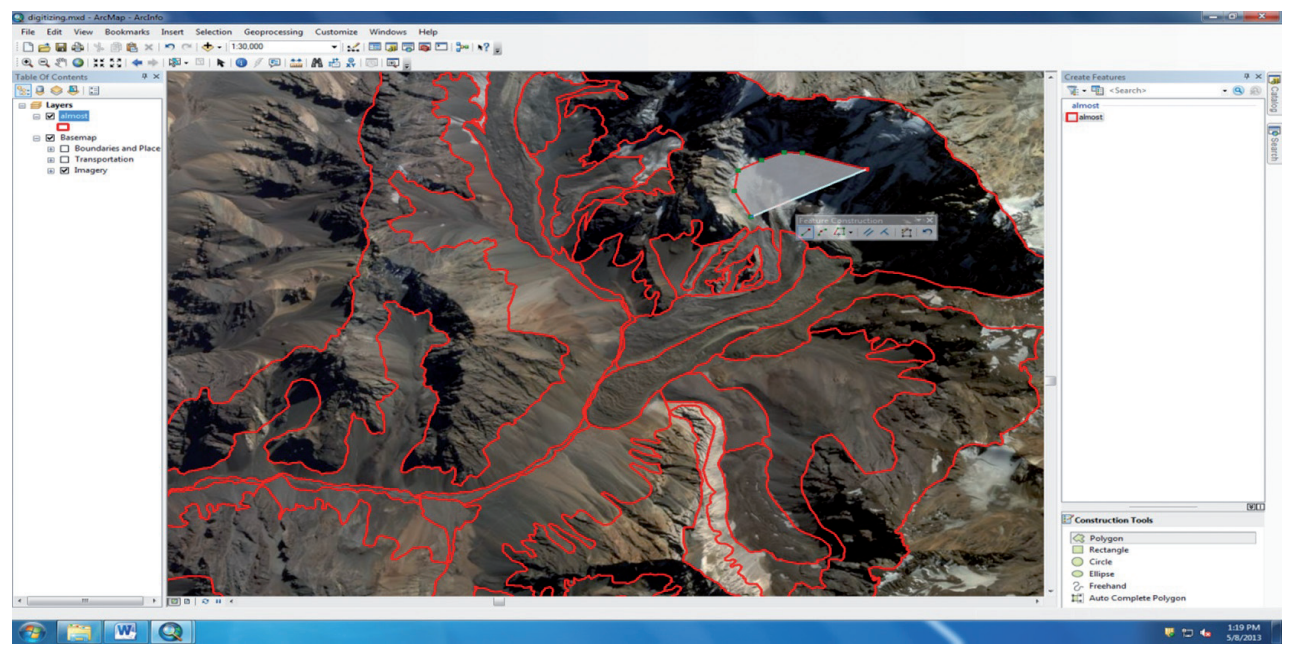

Fig. 3. An example of geologic feature polygons digitized into ArcGIS.

Because of the ability to generate forward and backward look angles, the RADARSAT-2 data is practical for generating a DEM (Fig. 4). A precise, high-resolution DEM was developed for the study area. The DEM was used to calculate slope and aspect of landforms. Field measurements were taken in the study area, Estero de Navarro, during March 2013. A GPS unit equipped with ArcPad was used to gather Ground Control Points (GCPs), gather information about the morphology and internal structure of glaciers, and install temperature data loggers for future projects. 


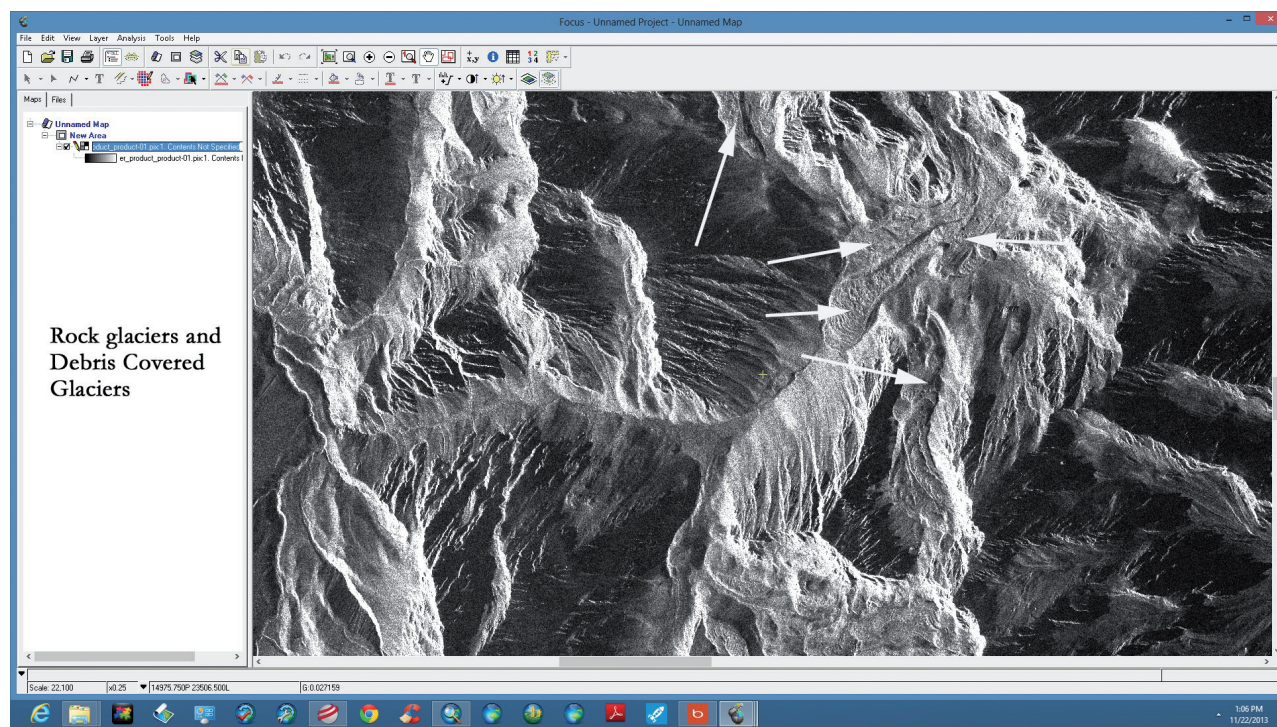

Fig. 4. Examples of rock glaciers and debris covered glaciers visible on the RADARSAT-2 imagery.

Within the Geomatica 2013 software, the OrthoEngine application was used to build a DEM based on overlapping SAR images. Control and tie points were generated in the OrthoEngine application to build a model.
This was used to construct and project a $1 \mathrm{~m}$ DEM that was imported into ArcGIS. Surface Spatial Analysis tools available in ArcToolbox were used to calculate slope, hillshade, aspect, and curvature (Fig. 5). 


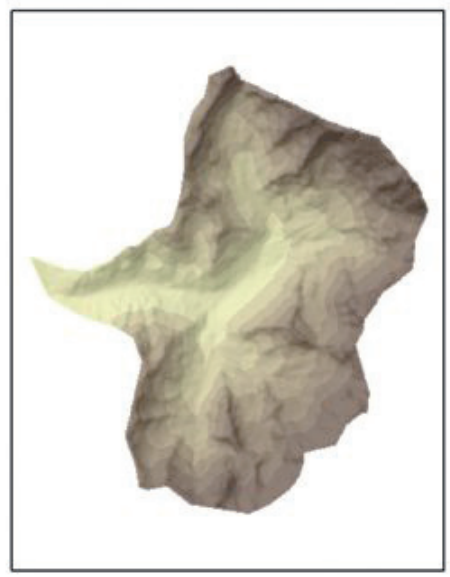

\section{Elevation}
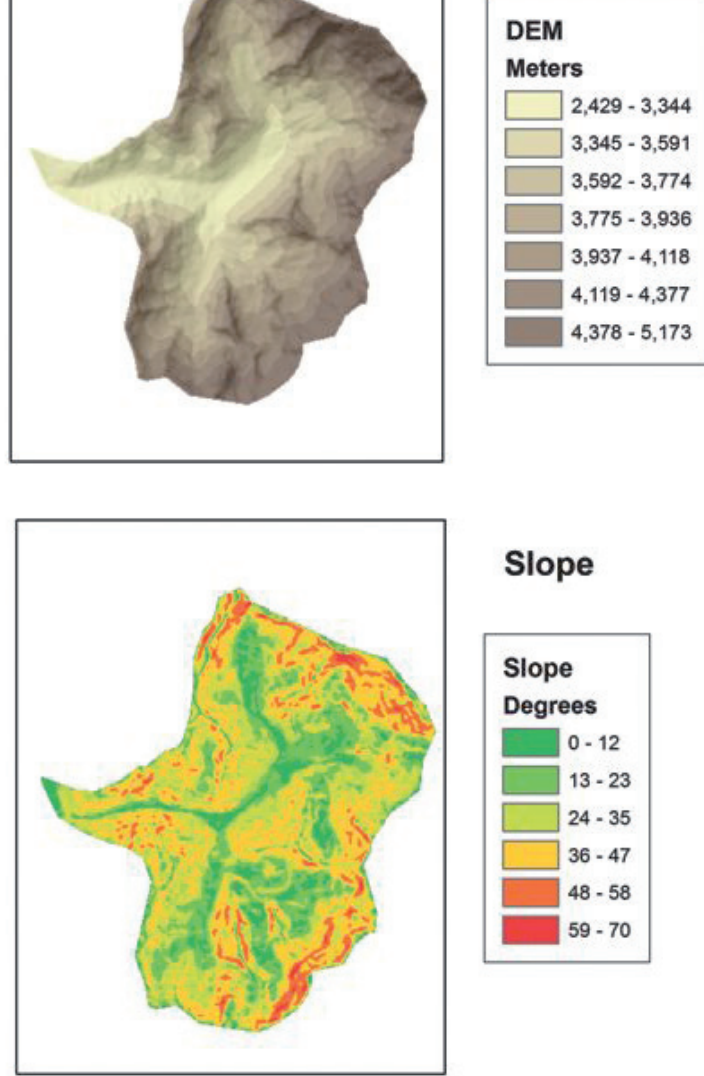

\section{Slope}
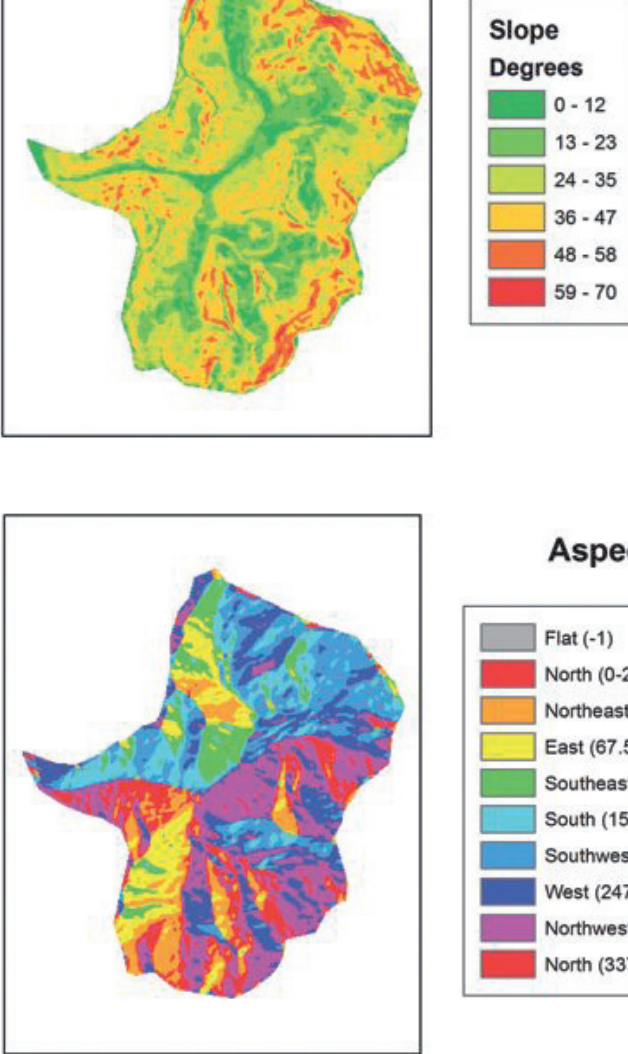

Aspect

\begin{tabular}{|l|}
\hline Flat (-1) \\
North (0-22.5) \\
Northeast (22.5-67.5) \\
\hline East (67.5-112.5) \\
Southeast (112.5-157.5) \\
South (157.5-202.5) \\
Southwest (202.5-247.5) \\
West (247.5-292.5) \\
Northwest (292.5-337.5) \\
North (337.5-360) \\
\hline
\end{tabular}

0

10 20 Kilometers

Fig. 5. Elevation, slope, and aspect raster datasets generated from the DEM created using the SAR imagery. 
The landform layer was overlaid on the DEM, slope, and aspect raster datasets (Fig. 6). Using a zonal statistics function in ArcToolbox, a mean condition was calculated for each geology type. Areas were calculated using a utility in ArcGIS. The table of the geology polygon layer was edited by adding a function to column that estimates ice content based on area. These values were summarized for each landform feature to calculate the total volume of water contained in the study area. The data produced by this study allows quantifying the amount of water stored in the glaciers. Officials can use this information to develop effective management strategies and conservation efforts of water resources. The method of data collection and analysis used in this case study could also be used to improve the identification process and apply it to larger watersheds, such as the Aconcagua and the Maipo, or other sections of the Central Andes where water is facing scarcity.

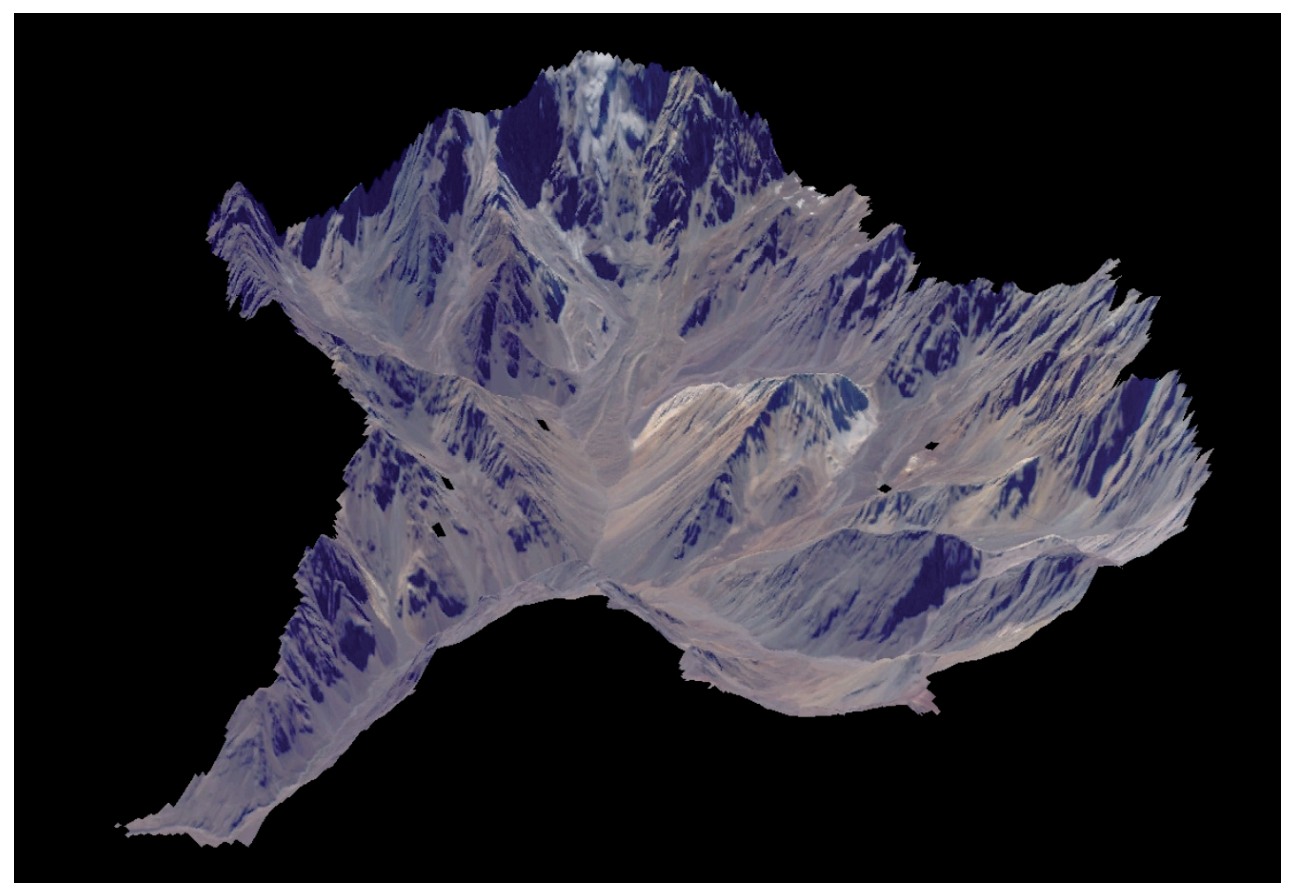

Fig. 6. 3-D representation of the study area using a DEM and RapidEye imagery.

The glacial features were classified into three groups based on morphology and ice content: (1) Ice and Snow, including uncovered 'glaciers' and firn; (2) Debris Covered Glaciers; (3) Rock Glaciers of Glacial Origen; and (4) Periglacial
Rock Glaciers or Tallus. Only two small Periglacial Rock Glaciers were identified. Due to their small size, they were included in the total for the Rock Glaciers category, but were displayed independently in the maps (Fig. 7, 8, 9). 


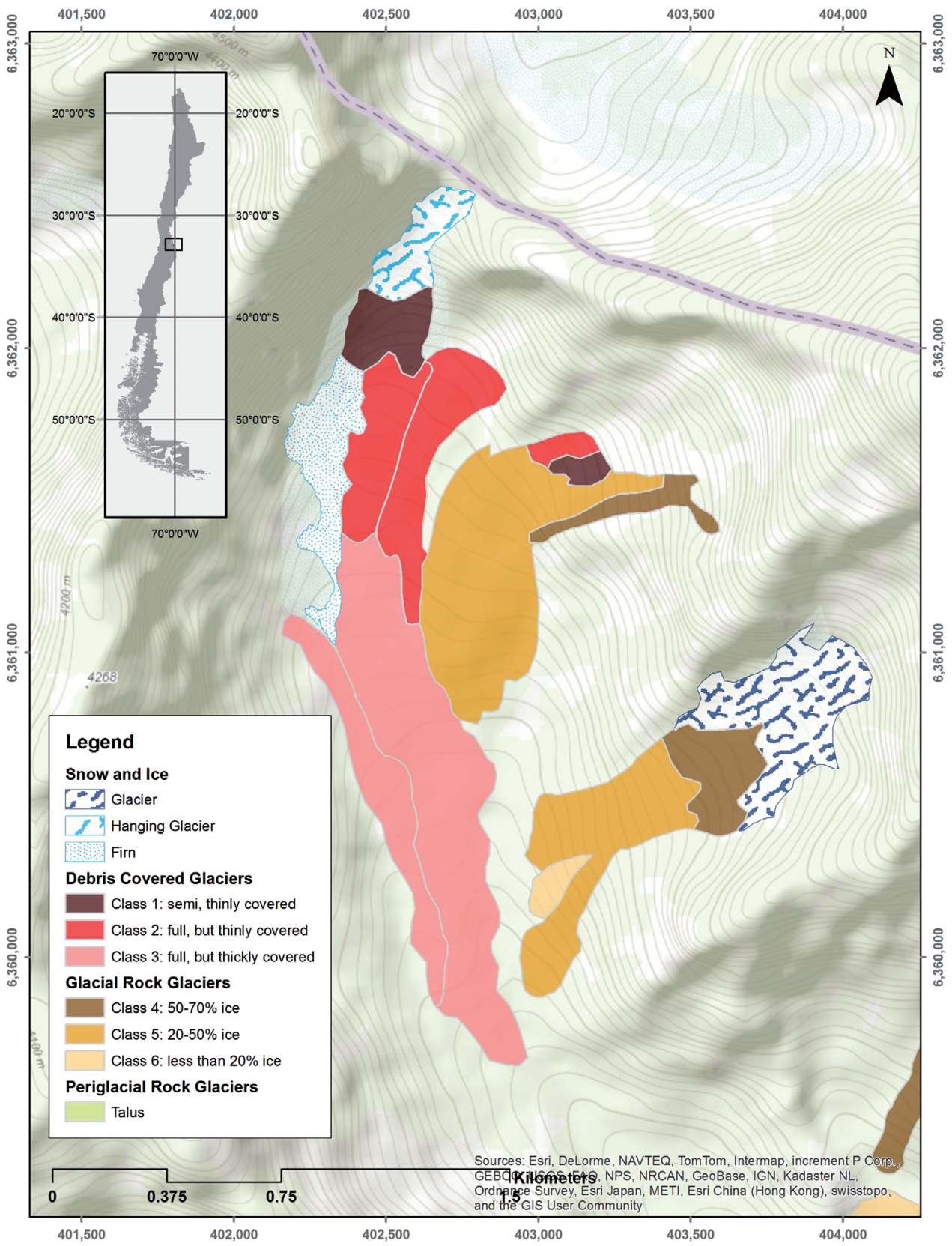

Fig. 7. Glacier inventory map for the Estero de Navarro (NE quadrant). Debris covered glaciers are represented in the red color ramp according to the thickness of the debris cover. Rock glaciers are represented in brown color ramp according to ice content. 


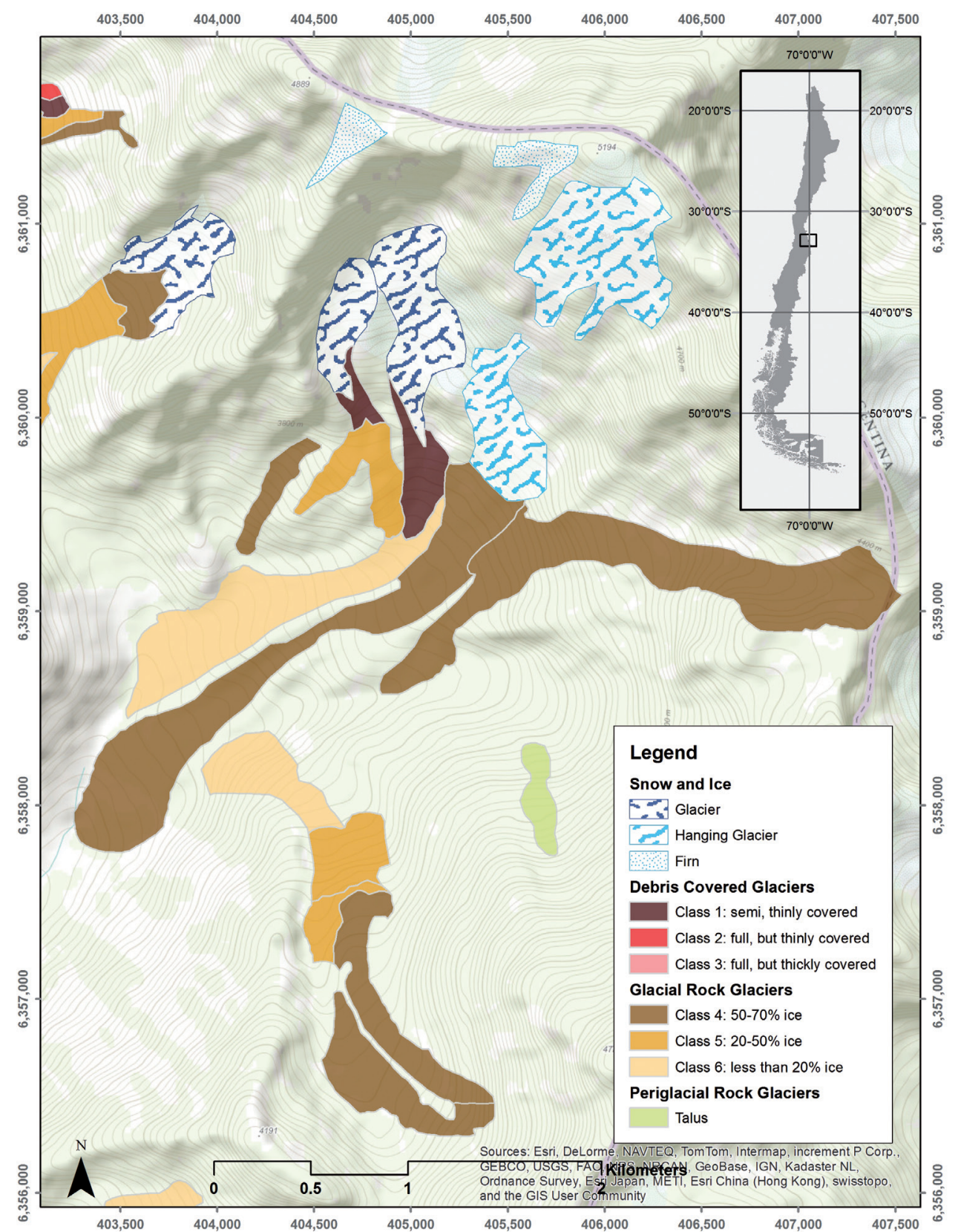

Fig. 8. Glacier inventory map for the Estero de Navarro (E quadrant). Debris covered glaciers are represented in the red color ramp according to the thickness of the debris cover. Rock glaciers are represented in brown color ramp according to ice content. 


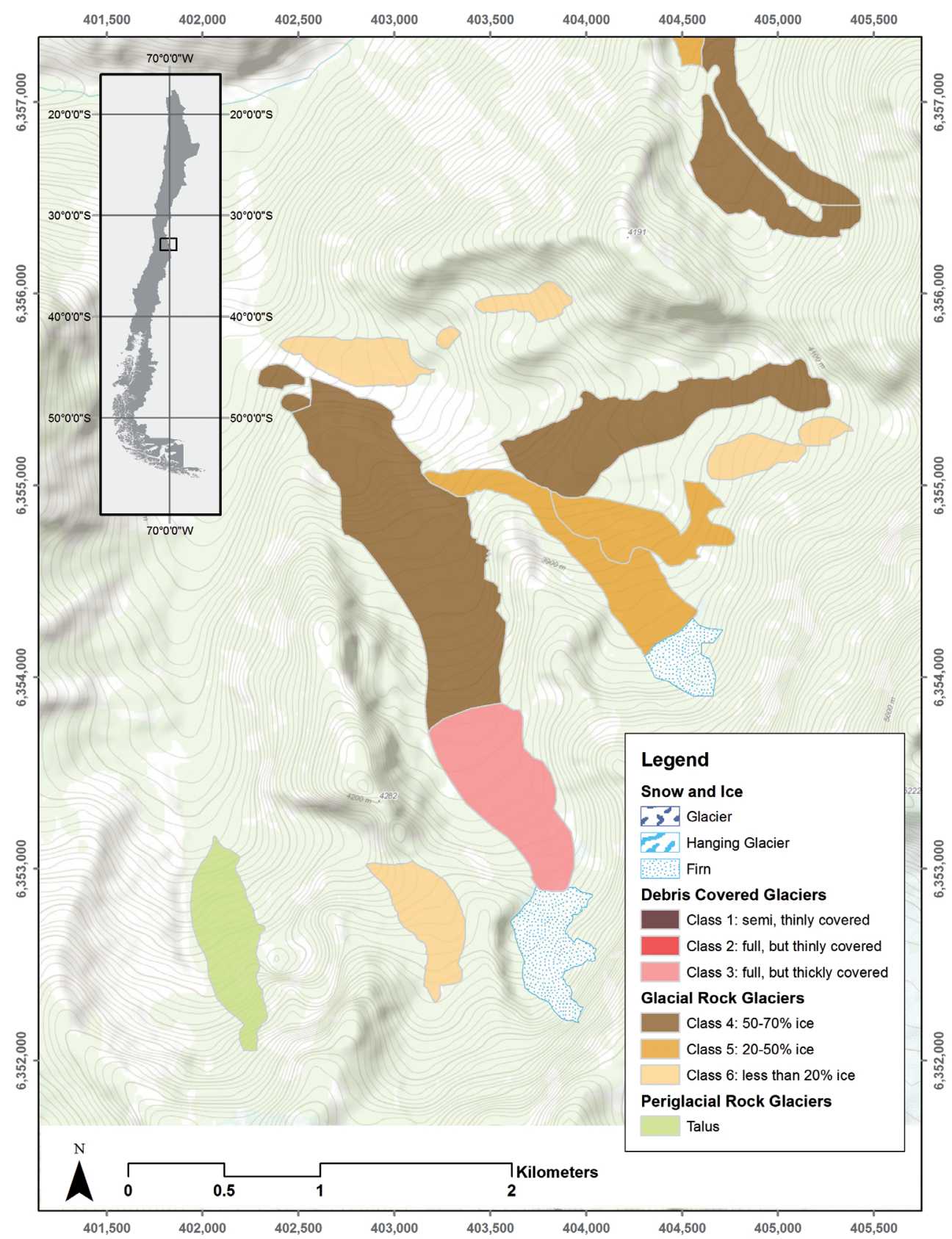

Fig. 9. Glacier inventory map for the Estero de Navarro (SE quadrant). Debris covered glaciers are represented in the red color ramp according to the thickness of the debris cover. Rock glaciers are represented in brown color ramp according to ice content. 
The Estero de Navarro has a total surface area of $\sim 84 \mathrm{Km}^{2}$; the total calculated glaciated area of this sub-catchment is $13.6 \mathrm{Km}^{2}$. Debris covered glaciers and rock glaciers cover about 4.2 times more area that glaciers and firn, or $80.8 \%$ of the total glaciated area (Table 2). They are generally located at lower elevations ( 3700 ma.s.l) and have gentler slopes than their uncovered glaciers counterparts.
The total estimated water volume of these glacial features of the cryosphere in the Estero Navarro sub-catchment is $1.55 \mathrm{Km}^{3}$. Debris covered glaciers and rock glaciers contain about $1.44 \mathrm{~km}^{3}$ of water, whereas glaciers and firn contain only about 0.11 $\mathrm{km}^{3}$ of water. Debris covered glaciers and rock glaciers account for roughly $93 \%$ of the water stored in the Estero de Navarro sub-catchment.

TAble 2. Summary Measurements OF GLACIER TYPes IN THE ESTERO DE NAVARRO SUB-CATChMENT.

\begin{tabular}{|c|c|c|c|c|c|c|}
\hline Glacier type & $\begin{array}{c}\text { Area } \\
\left(\mathrm{km}^{2}\right)\end{array}$ & $\begin{array}{c}\text { Percentage of } \\
\text { Total Area }\end{array}$ & $\begin{array}{c}\text { Mean Eleva- } \\
\text { tion }(\mathrm{m})\end{array}$ & $\begin{array}{c}\text { Mean } \\
\text { Slope }\left(^{\circ}\right)\end{array}$ & $\begin{array}{c}\text { Water } \\
\left(\mathrm{km}^{3}\right)\end{array}$ & $\begin{array}{c}\text { Percentage of } \\
\text { Total Water }\end{array}$ \\
\hline $\begin{array}{c}\text { Debris Covered } \\
\text { Glacier }\end{array}$ & 1.9 & $13.90 \%$ & 3783 & 14.3 & 1.216 & $78.50 \%$ \\
\hline Rock Glacier & 9.1 & $66.90 \%$ & 3747 & 18.6 & 0.22 & $14.20 \%$ \\
\hline Glacier & 1.9 & $13.90 \%$ & 4262 & 32.9 & 0.086 & $5.50 \%$ \\
\hline Firn & 0.7 & $5.10 \%$ & 4251 & 27.1 & 0.028 & $1.80 \%$ \\
\hline TOTAL & 13.6 & $100.00 \%$ & & & 1.55 & $100.00 \%$ \\
\hline
\end{tabular}

This methodology could be used to more accurately map not only the extent of different glaciers, but also, and perhaps most importantly, to calculate their water content in the form of stored ice in the Central Andes of Chile. The knowledge of the extent and water content of debris covered glaciers and rock glaciers in Chile are scarce and the few studies that have inventoried glaciers might have underestimated this type of glaciers. For example, BOWN et al. (2008) conducted the most recent glacier inventory in the Aconcagua Basin using images of Landsat 7 and ASTER imagery. The authors note that there are 159 glaciers in the upper Aconcagua River Basin with a calculated glaciated area of $121 \mathrm{Km}^{2}$, of which $34 \%$ consist of debris covered glaciers (BOWN et al. 2008). In this Aconcagua inventory no rock glaciers were reported $(\mathrm{BOWN}$ et al. 2008). According to the preliminary finding of this research team, more than 700 debris covered glaciers and rock glaciers have been identified in an in-progress glacier inventory of the Aconcagua River Basin that uses this methodology. This is an outstanding difference between two inventories of the same basin. However, it should be noted that these two inventories are not comparable due to the difference in the spatial resolution of the imagery being used. This team is working with a spatial resolution of $1 \mathrm{~m}$, whereas BOWN et al. (2008) worked with imagery of a spatial resolution of 15-30 m. And, in accordance with the results found for the Estero de Navarro sub-catchment, debris covered glaciers and rock glaciers comprise more than $60 \%$ of the total glaciated area and hold about $70 \%$ of the water equivalent in the form of ice in the upper Aconcagua Basin. 
This is an important finding that should inform glacier policy and sustainable water management in Chile: Debris covered glaciers and rock glaciers might be one of the most important source of water from ice in the Central Andes. During the summer months, they play a critical role in maintaining runoff.

\section{Mining Expansion and Water Resources: CODELCO's Expansión Andina 244}

Northern Chile is the center of one of the world's most important deposits of mineral resources. Recent mining expansion in this area is causing water conflicts with local communities because of the increasing competition for water resources. These mining projects need large quantities of water to operate, which are extremely limited in an arid region. The water withdrawals from surface and ground resources of these large projects are supported by a legislation that favors the privatization of water property rights and the commoditization of natural resources. Large mining projects are overusing water in the upper catchments, damaging and destroying glaciers, and contaminating water supplies. These actions are threatening the sustainability of water supplies downstream from the mines for human consumption, agriculture, conservation areas, protected ecosystems and for indigenous communities (LARRAÍN \& POO 2010). The partial removal of rock glaciers in the upper catchment of the Choapa river basin $\left(31.6^{\circ} \mathrm{S}\right)$ by the Pelambres mining project (AZÓCAR \& BRENNING 2008); and the serious environmental violations (among others, the failure to contain contaminated mining runoff into the river and damaging interventions on the local glaciers) by the mining giant Barrick Gold Corp. in its \$ 8.5 billon Pascua-Lama project located in the upper Huasco river basin, are well documented cases illustrating how the minerals industry interacts with water, negatively affecting the environment and local communities (KEMP et al. 2010).

The most recent mining expansion project is CODELCO's for the expansion of its open-pit copper mine Andina. The project aims to expand the treatment capacity of mineral ore by 152,000 tons per day, from its current annual average of 92,000 to 244,000 tons per day, to achieve an average annual production of 600,000 tons of copper. The project, referred to as Expansión Andina 244, is located in the Andean highlands of the upper Aconcagua River, only 30 kilometers (18 miles) to the northeast of the city of Santiago. This project, with an estimated cost of up to 6.8 billion dollars, would create one of the largest mining operations in the world and would have serious social and ecological impacts on a large area. The project's direct and indirect environmental impacts would cover a large area of influence overlapping the major urban settlements of Santiago and Valparaiso, protected natural areas, water catchments, and rich agricultural lands. As a result, the proposal has been received with discontent by the general public and is generating organized opposition by broad sectors of civil society.

The mine is located right next to of one of the most important system of glaciers of central Chile that feed the upper catchments of the Aconcagua and the Mapocho river basins. Indeed, the area of the mountain divide between the Aconcagua River Basin and the Maipo river basin is covered by one of the largest fields of glaciers in Central Chile: the Olivares Glacier Field. With the accompanying debris-covered glaciers and rock glaciers, this glacier field, provides water for the catchments of important river systems. Their hydrological and environmental services are invaluable; any alteration in their environment could have serious effects in the medium term; inter alia, on the water supply in the regions of Valparaiso and Metropolitan Santiago (Fig. 10). 


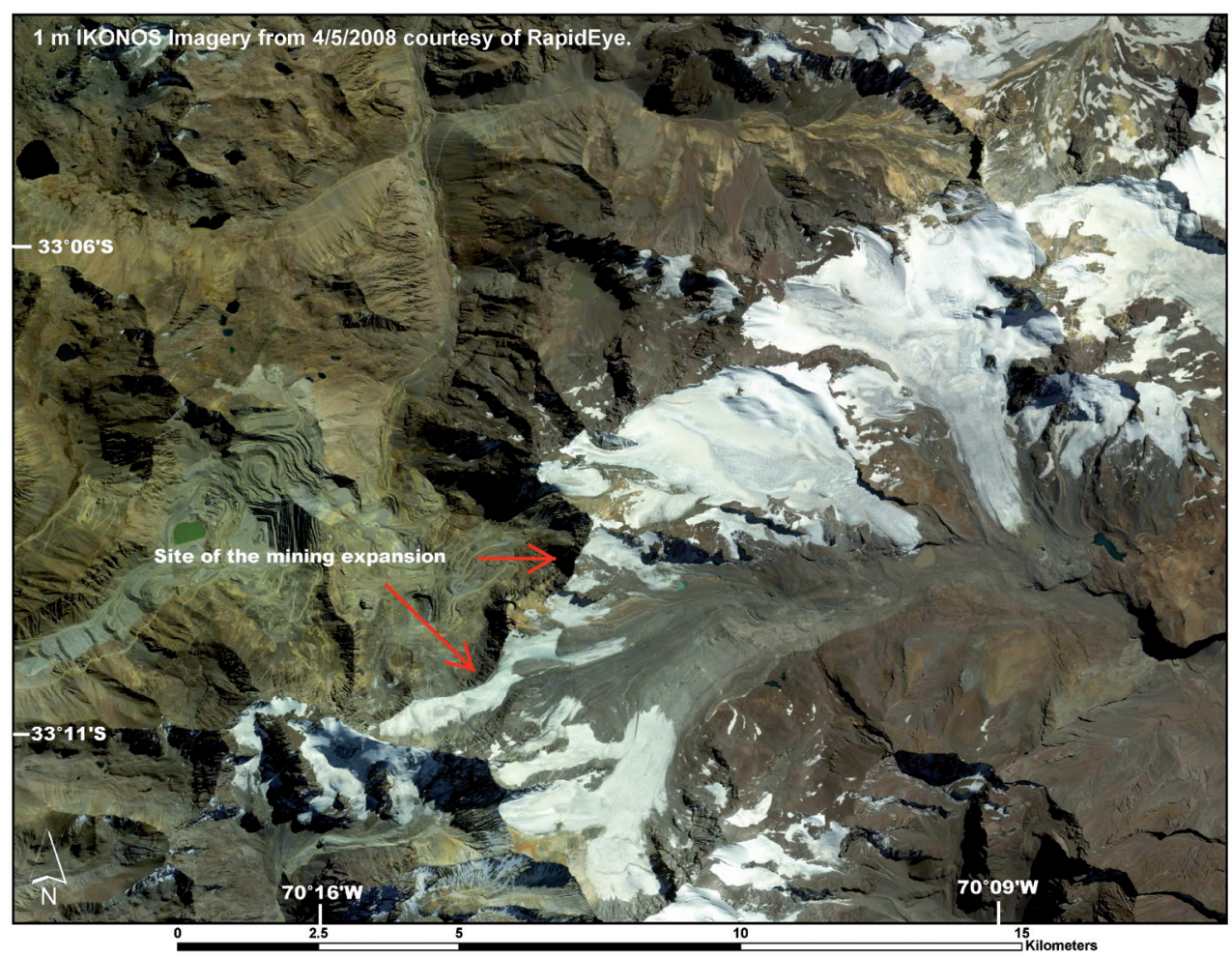

Fig. 10. Satellite image illustrating the proximity of CODELCO's Andina mine to the system of glaciers of Central Chile, IKONOS $1 \mathrm{~m}$ imagery.

Therefore, it is very important to consider that the expansion of the mining operations that CODELCO is proposing in the high Andes would not only generate strong local direct impacts, but also the indirect impacts would be of a potentially great magnitude over a larger geographical area. The most important, direct and indirect, impacts related to the hydrological system are the following:

Effects on Glaciers and on Water: The project contemplates the destruction of some rock glaciers by excavations while others will be covered with mining tailings. Also, the project will have indirect effects on the adjacent system of glaciers. The destruction of glaciers and the acceleration of glacier decline will be the most damaging local effects that the expansion of this large mining operation could have in the hydrological system, reducing water reserves in the medium and long term. The effects downstream will be the reduction of river runoff and the chemical quality of the water would also be compromised. These impacts on the hydrological system could negatively impact the rich agricultural production of fruit and wines that are presently carried out in the Aconcagua and in the Maipo Valleys by the progressive decline in the availability of water for irrigation and the increasing toxicity in water for plants. A reduction in runoff, would also compromise the availability of water for human consumption, for the same reasons, water scarcity and the contamination of surface and groundwater.

Mine Rock Blasting: In open pit mines, the seismic waves generated by daily rock surface blasting to loosen mineral ore usually have a regional effect beyond the mining sites. These blastings destabilize adjacent glaciers, and may increase the rate of ice melt by inducing internal friction. Material falling off slope may destabilize the active layer of glaciers increasing melting. 
Dust and changes in the albedo: The same rock surface blasting generates clouds of fine particulate matter that are transported and deposited in adjacent glaciers and snowfields through wind activity or aeolian processes. This can cause a sharp increase in ice melt by altering the albedo. This, ( $>$ $10 \mathrm{cms}$ thickness) dark dust will absorb insolation rather than reflecting it back to the atmosphere as in light colored surfaces such as snow.

Pollution: Large-scale mining releases a number of trace metals and pollutants that increase the natural concentration of these pollutants or incorporate new chemical compounds into the waters. These pollutants move downstream into rivers causing adverse effects on the natural and anthropic environment. Mining tailings are sources of acid mine drainage which is one of mining's most serious threats to water that can devastate rivers, streams, and aquatic life for many years. To this, we must add the pollution emissions generated by trucks, such as $\mathrm{NO}_{2}$ and $\mathrm{CO}_{2}$, which increase acid deposition and are greenhouse gases. The water carried to the ocean by the impacted rivers would have higher contents of trace chemical compounds and minerals and an increased turbidity beyond their normal composition, so that fish, mollusks and crustaceans that inhabit the coastal ecosystem nearby the mouth of the river areas would be biologically affected by the contamination. This toxicity, as we know, is easily transmitted to the upper links in the food web.

Protected natural areas: In the vicinity of the expansion of the mining project, in the upper Aconcagua and the Mapocho river basins, there are protected areas for their ecological relevance, which will be impacted by the processes mentioned above, in addition to habitat destruction in the mining site.

All these spillover effects that the expansion of large mining operations could trigger on both the glacier system and the hydrologic system should be examined at the regional scale. The effects of the high altitude mining operation cascade and accumulate downstream, eventually reaching the Pacific Ocean. All of the above impacts would entail socioeconomic effects of growing magnitude derived from the environmental consequences of a diminished ecology, from the negative effects on the productive activities, and from the negative impacts on human health.

Whereas no mitigation activities could assure that the natural system would be minimally impacted by this mining project, and that sustainable development can only be achieved if approached from a long-term perspective, it is not considered advisable to implement the mining intervention currently being proposed by the state-owned company. This nexus between CODELCO and the Chilean state becomes more salient when it is noted that the Chilean government, by constitutional mandate, is the guarantor of citizens' rights to live in a pollution free environment and to ensure the conservation of natural resources.

In sum, all the consequences that undoubtedly would arise from the mining intervention in the Andean highlands, especially of the magnitude proposed by the CODELCO Project, make clear that the potential environmental losses for many areas far outweigh any projected profit.

\section{DISCUSSION}

\section{Chilean Glaciers as Sources of Water Supply}

The high altitude environments of the Andes in Chile hold a large number of glaciers. Chile has a glacier area of 20.190 $\mathrm{Km}^{2}$, concentrating approximately $77 \%$ of the South American total (DIRECCIÓN GENERAL DE AGUAS 2012). A recent symposium on Andean Glaciology concluded: "Except for a few cases in Patagonia and Tierra del Fuego, glaciers in 
South America have shown a generalized retreat and wasting, in agreement with the global trend" (EDITORIAL GLOBAL AND PLANETARY CHANGE 2007: 1).

The Dirección General de Aguas (the National Water Directorate, hereafter DGA) is the office that manages water allocation among different uses. In 2008, this office elaborated the National Strategy of Glaciers with the general objective of providing guidelines for future research on glaciers. The general objective of this strategy is to enhance the knowledge of glaciers as the country moves toward developing a comprehensive normative framework for the regulation of glaciers. The specific objectives of this national strategy are: (1) to generate comprehensive scientific and technical knowledge of Chilean glaciers. (2) To identify the effects of human actions on the glaciers. (3) To create an official inventory of glaciers and a system to regularly update their technical information.
(4) And, to implement pilot activities for monitoring glaciers (CENTRO DE ESTUDIOS CIENTÍFICOS 2009).

To date, about 1,835 glaciers have been inventoried, covering an area of $15,490 \mathrm{Km}^{2}$. But there is an estimated glaciated area of $4,700 \mathrm{Km}^{2}$ that still needs to be inventoried (Table 3). Only some rock glaciers have been identified but not properly registered. Rock glaciers are important sources of water in arid and semiarid regions (AZÓCAR \& BRENNING, 2010). This research team estimates that, in the Central Andes, rock and debris covered glaciers are smaller but more abundant than glaciers senso stricto and hold an important percentage of the total glaciated area in many basins and water. However, these sources of water have not been properly inventoried, limiting a complete assessment of the country's water sources, and also making them susceptible to negative human intervention, especially from mining (BORQUÉZ et al. 2006).

Table 3. Current glacier InVentory

\begin{tabular}{|c|c|c|c|c|}
\hline Zone & Basin & $\begin{array}{c}\text { Number of } \\
\text { Glaciers }\end{array}$ & Area Km2 & $\begin{array}{c}\text { Rock Glaciers as \% } \\
\text { of total area }\end{array}$ \\
\hline North $\left(\right.$ Lat. $18^{\circ}-32^{\circ}$ ) & Atacama & 28 & 41 & Non-inventoried \\
\hline Center (Lat. $32^{\circ}-37^{\circ}$ ) & Semi-Arid & 60 & 73 & Non-inventoried \\
\hline & Aconcagua & 159 & 121 & Non-inventoried \\
\hline & Maipo & 647 & 422 & $39 \%$ \\
\hline & Cachapoal & 146 & 222 & $21 \%$ \\
\hline Tinguiririca & 261 & 106 & $3 \%$ \\
\hline South (Lat. $37^{\circ}-42^{\circ}$ ) & Mataquito & 81 & 32 & Non-inventoried \\
\hline Patagonia (Lat. $\left.42^{\circ}-56^{\circ}\right)$ & Maule & 98 & 35 & $20 \%$ \\
\hline Total Inventoried & & 106 & 273 & $14 \%$ \\
\hline Non-inventoried & & 249 & 14,164 & $4 \%$ \\
\hline TOTAL & & 1,835 & 15,489 & \\
\hline
\end{tabular}

Source: BORQUÉZ et al. (2006)

Current levels and future projections of greenhouse gas emissions in the atmosphere indicate that the planet is experiencing accelerated environmental change. Snowfall decline and glacier retreat caused by climatic change is currently happening worldwide and is affecting water supply. Due to the importance of glaciers and snowfall as indicators of climate change, studying the high Andean environment 
provides meaningful observations as to their evolution, and their associated impact on future water supply for much of southern South America.

Although South America contains the second largest reservoir of fresh water in the world, its population is vulnerable to water scarcity. Watersheds in the region are dependent on snowfall and glacial melt from the high mountain systems. Glaciers release water during the dry-season, insuring year-round water flow for cities, agricultural production, and industry that may not be available in the near future. Millions of people especially in South American cities depend on Andean watersheds for potable water, agriculture, and hydroelectric power generation. Glaciers in the South American high Andean systems are currently receding at alarming and ever increasing rates. In some cases, glaciers have completely vanished. Andean cities will have to adapt to this increasing water scarcity challenge while maintaining their ability to sustain urban economies.

Whereas as Chile's water resources depend heavily on glaciers, the country does not have legislation to protect them. The Chilean water code has no legal definition for glaciers. Currently, civil society actors and the government are working to develop a policy proposal to provide the country with the legal framework for the protection and conservation of glaciers centered on the Integrated River Basin Management(IRBM) approach (COMISIÓN NACIONAL DE MEDIO AMBIENTE 2009). Currently, the only normative protecting glaciers is the changes that were introduced in the normative of the country's environmental impact assessment in 2008; stating that an impact assessment should be conducted every time a project would affect glaciers.

Furthermore, in 1997 Chile and Argentina signed The Treaty for Mining Integration, facilitating the development of mining on the high Andes, on a delimited strip of land on either side of the limit between the two countries. The limit between
Chile and Argentina comprises the highest peaks that divide the Pacific from the Atlantic basins (the continental divide). This treaty provides the framework for the development of bilateral mining projects on the frontier between both countries. The strip of land covered by this treaty coincides exactly with the highest peaks of the Andes and with the area that contains the largest amount of glaciers, and with headwaters or catchment zones of the Andean river basins. This poses a high risk of mining intervention into critical areas that provide pivotal environmental services, such as water for human consumption and water for agricultural irrigation for food production. Moreover, about $70 \%$ of Chile's total population of 17 million inhabitants obtains its water supply from the high Andean basins, and agriculture is most dependent on the same basins for irrigation. To date four large mining projects in the high Andes have been approved under this treaty (BORQUÉZ et al. 2006).

A recent study surveying glacier vulnerability found, after reviewing data from a sample of 100 glaciers, that $87 \%$ of the glaciers in the sample showed generalized retreat and wasting, 7\% were stable, and only $6 \%$ showed advances (RIVERA et al. 2000). In general, scientists agree that in the last decades the majority of Chilean glaciers are following the global trend of generalized retreat linked to higher atmospheric temperatures, decreased annual precipitation, and increased rainfall variability (BOWN et al. 2008; NICHOLSON et al. 2010; RIVERA et al. 2000; 2008). In Chile, glaciers continue to recede at alarming rates. In the future, the question remains whether there will be enough water for a growing population in Chile (JANKE \& BELLISARIO 2010). Because of their size and abundance, the amount of water stored per unit area in the Andes is in the order of a magnitude higher than in rock glaciers in the Alps (BRENNING 2008). Besides the challenges posed by climatic change, Chilean glaciers are threatened by human activities. 
Indeed, mining is the economic activity that poses the highest risk to the glaciers in the Chilean Andes. There have been many documented instances where uncovered glaciers and rock glaciers have been destroyed by mining and related activities (BRENNING 2008; BRENNING \& AZÓCAR 2010). The Chilean mining code does not limit mining in fragile or special ecosystems. On the contrary, the nation's mining code allows prospection and mining in almost every parcel of the nation's land including national parks.

\section{CONCLUSIONS}

The use of Geomatica 2013 and ArcGIS software in conjunction with IKONOS $1 \mathrm{~m}$ and RADARSAT-2 remotely sensed data proved an effective method to analyze alpine landforms with hydrological significance due to their ice content such as glaciers, firn (old snow), glacial rock glaciers, debris covered glaciers, and tallus, and evaluate associated water resources. CODELCO's proposal for the expansion of its open-pit copper mine Andina will have significant direct and indirect impacts over the hydrological system and the environment of a large area. The mitigation activities being proposed cannot assure that the natural system would be minimally impacted by this mining project. If a substantive conflict between development and the environment is to be aborted, and sustainable development is an important societal goal to be achieved, this research team does not consider it advisable to implement this mining intervention as the state-owned company is currently proposing.

The country lacks a sustainable water resource management plan to address the challenge to glaciers as important water sources. Chile needs to protect and preserve uncovered glaciers, debris covered glaciers, rock glaciers and periglacial areas and other fresh water sources that feed the watersheds, keeping mining and industrial activities outside these critical areas. Some possible important policies needed to respond to a future of water scarcity include, among other policies, the strengthening of glacier regulation laws. The Chilean economy is dependent on large-scale mining industries that are water "thirsty"; that is they are highly dependent on water and hydroelectricity. These mining activities are challenging the future sustainability of glaciers as sources of water. In the long term, the main water related challenge for Chile is to become water resilient due to water scarcity while at the same time finding strategies to meet increasing demands triggered by population and economic growth. The largest share of the country's population and the most important economic activities (mining and agriculture) are concentrated in the North and Central regions which are experiencing water scarcity due to prolonged droughts, decreased precipitation, and glacier retreat.

\section{REFERENCES}

AMARSAIKHAN, D., M. SAANDAR, M. GANZORIG, H.H. BLOTEVOGEL, E. EGSHIGLEN, R. GANTUYAL, B. NERGUI \& D. ENKHJARGAL, 2011. Comparison of multisource image fusion methods and land cover classification. International Journal of Remote Sensing, 33: 2532-2550.

ANGILLIERI, M. Y. E., 2010. Application of frequency ratio and logistic regression to active rock glacier occurrence in the Andes of San Juan, Argentina. Geomorphology, 114: 396-405.

AZÓCAR, G. F., \& BRENNING, A. 2008. Intervenciones en glaciares rocosos en Minera Los Pelambres, Región de Coquimbo. Chile. Technical Report, Unviersity of Waterloo. 14 pp.

AZÓCAR, G. F., \& BRENNING, A. 2010. Hydrological and geomorphological significance of rock glaciers in the dry Andes, Chile (27$\left.33^{\circ} \mathrm{S}\right)$. Permafrost and Periglacial Processes, 21(1): $42-53$.

BARONI, C., A. CARTON, \& R. SEPPI, 2004. Distribution and behaviour of rock glaciers in the Adamello-Presanella Massif (Italian alps). Permafrost and Periglacial Processes, 15: 243-259. 
BARSCH, D. \& N. CAINE, 1984. The nature of mountain geomorphology. Mountain Research and Development, 4:287-298.

BARSCH, D., 1996. Rockglaciers: Indicators for the Present and Former Geoecology in High Mountain Environments, Springer-Verlag, Berlin.

BENISTON, M., 2000. Environmental Change in Mountains and Uplands, Oxford University Press, New York.

BORQUÉZ, R., S. LARRAÍN, R. POLANCO \& J. URQUIDI, 2006. Glaciares Chilenos: Reservas estratégicas de agua dulce para la sociedad, los ecosistemas y la economía. Programa Chile Sustentable: Propuesta Cuidadana para el Cambio. Santiago, Chile: LOM Ediciones.

BOWN, F., A. RIVERA \& C. ACUNA, 2008. Recent Glacier Variations at the Aconcagua Basin, Central Chilean Andes. Annals of Glaciology, 48(1): 43-8.

BRENNING, A. \& D. TROMBOTTO, 2006. Logistic regression modeling of rock glacier and glacier distribution: Topographic and climatic controls in the semi-arid Andes. Geomorphology, 81: 141-154.

BRENNING, A. \& G. F. AZOCAR, 2010. Statistical Analysis of Topographic and Climatic Controls and Multispectral Signatures of Rock Glaciers in the Dry Andes, Chile (27 degrees-33 degrees S). Permafrost and Periglacial Processes, 21: 54-66.

BRENNING, A., 2009. Benchmarking classifiers to optimally integrate terrain analysis and multispectral remote sensing in automatic rock glacier detection. Remote Sensing of Environment, 113: 239-247.

BRENNING, A., 2008. The impact of mining on rock glaciers and glaciers: examples from Central Chile, in: Orlove, B.S., WIEGANDT, E., LUCKMAN, B. (Eds.), Darkening peaks: glacier retreat, science, and society, University of California Press, Berkeley, pp. 196-205.
BRENNING, A., 2009. Benchmarking classifiers to optimally integrate terrain analysis and multispectral remote sensing in automatic rock glacier detection. Remote Sensing of Environment, 113: 239-247.

BRENNING, A. \& D. TROMBOTTO, 2006. Logistic regression modeling of rock glacier and glacier distribution: Topographic and climatic controls in the semi-arid Andes. Geomorphology, 81: 141-154.

BUDDS, J., 2009. Contested H2O: Science, Policy and Politics in Water Resources Management in Chile. Geoforum, 40: 418-430.

BURGER, K. C., J. J. DEGENHARDT \& J. R. GIARDINO, 1999. Engineering geomorphology of rock glaciers. Geomorphology, 31: 93-132.

CENTRO DE ESTUdIOS CIENTÍFICOS (CECS), 2009. Estrategia Nacional de Glaciares: Fundamentos. DGA-MOP, Rep. de Chile. S.I.T. No 205-Diciembre 2009. 290 pp.

COMISIÓN NACIONAL DEL MEDIO AMBIENTE, 2009. Política para la protección y conservación de glaciares. Consejo Directivo CONAMA, Gobierno de Chile. 9 pp.

DIRECCIÓN GENERAL DE AGUAS (DGA), 2012. Análisis de Uso Actual y Futuro de los Recursos Hídricos de Chile. MOP-DGA. Informe Final. S.I.T. $N^{\circ} 26.487$ pp.

EDITORIAL: GLOBAL AND PLANETARY CHANGE, 2007. Current status of Andean Glaciers. Global and Planetary Change, 59: 1-9.

FERRANDO, F. 2003. Aspectos conceptuales y genetico-evolutivos de los glaciares rocosos: análisis de caso en los andes semiáridos de Chile. R. Gegr. De Chiel, Terra Australis, 48: 43-74.

GIARDINO, J. R. \& J. VITEK, 1988. The Significance of Rock Glaciers in the GlacialPeriglacial Landscape Continuum. Journal of Quarternary Science, 3: 97-103. 
GIARDINO, J. R. \& S. G. VICK, 1987. Geologic engineering aspects of rock glaciers, in: Giardino, J.R., F. Shroder, and J. D. VITEK (Ed.) Rock Glaciers, Allen and Unwin, Boston, pp. 265-287.

HABOUDANE, D., F. BONN, A. ROYER, S. SOMMER \& W. MEHL, 2002. Land degradation and erosion risk mapping by fusion of spectrally-based information and digital geomorphometric attributes. International Journal of Remote Sensing, 23: 3795-3820.

HAEBERLI, W., 2000. Modern research perspectives relating to permafrost creep and rock glaciers: A discussion. Permafrost and Periglacial Processes, 11: 290-293.

HUMLUM, O., 1998. The climatic significance of rock glaciers. Permafrost and Periglacial Processes, 9: 375-395.

HUMLUM, O., 2000. The geomorphic significance of rock glaciers: estimates of rock glacier debris volumes and headwall recession rates in West Greenland. Geomorphology, 35: 41-67.

JANKE, J. R., 2001. Rock glacier mapping: a method utilizing enhanced TM data and GIS modeling techniques, Geocarto International, 16: 5-15.

JANKE, J. R., 2007. Colorado Front Range rock glaciers: Distribution and topographic characteristics. Arctic Antarctic and Alpine Research, 39: 74-83.

JANKE, J. R. \& BELLISARIO, A., 2010. Geospatial Techniques to Assess High Mountain Hazards: A Case Study on California Rock Glacier and an Application for Management in the Andes, in: Hoalst-Pullen, N., Patterson, M. (Eds.), Geotechnologies and the Environment: Geospatial Technologies in Environmental Management, Berlín, pp. 65-84.

KÄÄB, A., 2005. Combination of SRTM3 and repeat ASTER data for deriving alpine glacier flow velocities in the Bhutan Himalaya. Remote Sensing of Environment, 94: 463-474.
KEMP, D., BOND, C. J., FRANKS, D. M \& COTE, C. 2010. Mining, water and human rights: making the connection. Journal of Cleaner Production, 18 (15): 1553-1562.

KONRAD, S. K. \& D. H. CLARK, 1998. Evidence for an early Neoglaciol glacier advance from rock glaciers Rind Lake sediments in the Sierra Nevada, California, USA. Arctic and Alpine Research, 30: 272-284.

LARRAÍN, S. AND POO, P. (Eds) CHILE SUSTENTABLE, 2010. Conflictos por el Agua en Chile: Entre los Derechos Humamos y las reglas del Mercado. Santiago: Gráfica Andes Ed. $362 \mathrm{pp}$.

NICHOLSON, L., J. MARIN, D. LOPEZ, A. RABATEL, F. BOWN \& A. RIVERA, 2010. Glacier inventory of the upper Huasco valley, Norte Chico, Chile: glacier characteristics, glacier change and comparison with central Chile. Annals of Glaciology, 50(53): 111-118.

PAUL, F., A. KAAB, M. MAISCH, T. KELLENBERGER \& W. HAEBERLI, 2002. The new remote-sensing-derived swiss glacier inventory: I. Method. Annals of Glaciology, 34: 355-361.

PELLICCIOTTI, F., P. BURLANDO \& $\mathrm{K}$. VAN VLIET, 2007. Recent trends in precipitation and streamflow in the Aconcagua River Basin, central Chile. Glacier Mass Balance Changes and Meltwater Discharge (selected papers from sessions at the IAHS Assembly in Foz do Iguaçu, Brazil, 2005). IAHS Publ, 318: 17-38.

RIVERA, A., G. CASSASA, C. ACUÑA \& H. LANGE, 2000. Variaciones recientes de glaciares en Chile. Invest. Geogr. Chile, 34: 29-60.

RIVERA, A., F. BOWN, C. ACUÑA \& F. ORDENES. 2008. Chilean glaciers as indicators of climate change. Terra Glacialis, 11: 193-207.

VITEK, J. D. \& J. GIARDINO, 1987. Rock glaciers: a review of the knowledge base, in: Giardino, J.R., Shroder, J.F., VITEK, J.D. (Eds.), Rock Glaciers, Allen and Unwin, Boston, pp. 1-26. 